\title{
Lability of RNA from the Large Cytoplasmic Ribosomal Subunit of the Protozoon Crithidia oncopelti
}

\author{
By ROSEMARY SPENCER* AND G. A. M. CROSS \\ M.R.C. Biochemical Parasitology Unit, Molteno Institute, Cambridge CB2 ${ }_{3} E E$
}

(Received I3 May 1975)

\begin{abstract}
SUMMARY
Cytoplasmic ribosomal RNA extracted from Crithidia oncopelti and analysed by gel electrophoresis at $4{ }^{\circ} \mathrm{C}$ consisted of two components, with molecular weights (relative to E. coli $\mathrm{rRNA}$ ) of $\mathrm{I} \cdot 30 \times 10^{6}$ and $0.83 \times 10^{6}$ daltons, present in equimolar amounts. On heating briefly at $5 \mathrm{I}{ }^{\circ} \mathrm{C}$ followed by rapid cooling, the $\mathrm{I} \cdot 30 \times 10^{6} \mathrm{RNA}$ completely dissociated into two components of molecular weights $0.70 \times 10^{6}$ and $0.56 \times 10^{6}$ (present in equimolar amounts). Fifty per cent dissociation of the molecule occurred at $28^{\circ} \mathrm{C}$. That the integrity of the RNA molecule at low temperatures is maintained by its secondary structure was confirmed by electrophoresis under denaturing conditions $(98 \%, \mathrm{v} / \mathrm{v}$, formamide). To account for these phenomena, latent cleavage of the molecule in vivo is proposed.
\end{abstract}

\section{INTRODUCTION}

RNA from the large ribosomal subunit (L-RNA) from a variety of protozoa (Loening, I968a; Stevens \& Pachler, I972; Bostock, Prescott \& Lauth, I97I), insects (Applebaum, Ebstein \& Wyatt, 1966; Greenberg, 1969; Ishikawa, I973; Shine \& Dalgarno, 1973), bacteria (Lessie, 1965; Borda, Green \& Kamen, 1969) and chloroplasts (Ingle, 1968; Leaver, 1973) dissociates non-enzymically into two components of approximately the same size as the small subunit RNA (S-RNA). Dissociation of L-RNA occurs under conditions which cause disruption of non-covalent (hydrogen) bonds maintaining secondary structure (Herskovits, 1962; Cox \& Littauer, 1962); the phenomenon is thought to reflect enzymic cleavage of the RNA in vivo in a single-stranded region of the molecule. In favourable conditions (high salt concentrations and low temperatures) the extracted molecules are held together by their secondary structure and the cleavage point is therefore only detectable under denaturing conditions.

This paper describes the presence of thermolabile L-RNA in the trypanosomatid flagellate Crithidia oncopelti, and it is suggested the cause of the break is enzymic cleavage of the molecule occurring in viro.

\section{METHODS}

Organisms and growth conditions. Crithidia oncopelti was grown axenically in peptoneglucose medium (Newton, 1957). For experimental purposes, $500 \mathrm{ml}$ batch cultures were harvested in mid-exponential phase of growth $\left(2 \times 10^{7}\right.$ cells $\left./ \mathrm{ml}\right)$.

Escherichia coli (strain MRE600) was obtained as a frozen cake from the Microbiological Research Establishment, Porton Down, Wiltshire, and stored at $-20{ }^{\circ} \mathrm{C}$.

* Present address: University of Cambridge and Medical Research Council, Dunn Nutritional Laboratory, Cambridge CB4 IXJ. 
RNA extraction. High molecular weight RNA was extracted from cells (Kirby, I965; Parish \& Kirby 1966 ), and stored at $-20{ }^{\circ} \mathrm{C}$ as an ethanolic suspension in $0.15 \mathrm{M}$-sodium acetate $0.5 \%(\mathrm{w} / \mathrm{v})$ sodium dodecyl sulphate (SDS) $(2: \mathrm{I}, \mathrm{v} / \mathrm{v}), \mathrm{pH} 6.0$. The RNA concentration was estimated from its extinction at $260 \mathrm{~nm}$, assuming an $E_{1 \text { cin }}^{1^{\prime \prime}}$ of 250 .

RNA was dissociated from $C$. oncopelti ribosomes (prepared by the method of Cross, 1970 , and stored in small portions at $-195^{\circ} \mathrm{C}$ in $50 \mathrm{~mm}-\mathrm{KCl}, 10 \mathrm{~mm}$-magnesium acetate, $50 \mathrm{~mm}$-tris- $\mathrm{HCl}, \mathrm{pH} 7 \cdot 6$ ) by dilution to the required concentration with gel running buffer containing either $0.05 \%(\mathrm{w} / \mathrm{v}) \mathrm{SDS}$ (for electrophoresis at $4{ }^{\circ} \mathrm{C}$ ) or $0.2 \%$ (for electrophoresis at room temperature).

$R N A$ analysis. RNA ( 5 to $40 \mu \mathrm{g}$ in 5 to $60 \mu \mathrm{l}$ ) was analysed by polyacrylamide gel electrophoresis (Loening, 1968b) on $2.6 \%(\mathrm{w} / \mathrm{v})$ acrylamide gels at $4{ }^{\circ} \mathrm{C}$ or at room temperature. The running buffer (acetate buffer) contained 20 mM-sodium acetate, 2 mM-EDTA, 40 mmtris- $\mathrm{HCl}, \mathrm{pH} 7.8$ (plus $0.2 \%, \mathrm{w} / \mathrm{v}, \mathrm{SDS}$ at room temperature only). Phosphate buffer (30 mM- $\mathrm{NaH}_{2} \mathrm{PO}_{4}$, I mM-EDTA, $36 \mathrm{~mm}$-tris- $\mathrm{HCl}, \mathrm{pH} 7 \cdot 6$, plus $0 \cdot 2 \%$, w/v, SDS) was employed occasionally for electrophoresis at room temperature. Electrophoresis in denaturing conditions was performed at room temperature according to Staynov, Pinder \& Gratzer (1972), using $4 \%(\mathrm{w} / \mathrm{v})$ gels in $98 \%(\mathrm{v} / \mathrm{v})$ formamide containing $20 \mathrm{~mm}-\mathrm{NaCl}, \mathrm{pH} 9 \cdot 8$.

Gels were scanned at $265 \mathrm{~nm}$ in a Joyce-Loebl ultraviolet scanner. The apparent molecular weights of RNAs were calculated from their electrophoretic mobility relative to the two E. coli rRNAs (molecular weights taken as $1.07 \times 10^{6}$ and $0.56 \times 10^{6}$ daltons) present as internal markers, assuming the mobility of RNA is inversely related to the logarithm of its molecular weight (Loening, 1967; Bishop, Claybrook \& Spiegelman, 1967). The molar concentration of each RNA species present was calculated from the area of its peak (determined using a planimeter) and the calculated molecular weight. In all Figures the molecular weights of RNA components are designated as daltons $\times 10^{-6}$.

\section{RESULTS}

rRNA from $C$. oncopelti, when extracted and analysed at $4{ }^{\circ} \mathrm{C}$, contained L-RNA of molecular weight $1.30 \times 10^{6}$ and S-RNA of molecular weight $0.83 \times 10^{6}$ in the molar ratio I $0: 1 \cdot 07$ (Fig. I $a$ ). The additional minor components were coincidental with $E$. coli rRNA, and were derived from the bipolar body of the flagellate (Spencer \& Cross, 1975). In contrast, rRNA from the same extract electrophoresed at $25{ }^{\circ} \mathrm{C}$ contained a much lower amount of $1 \cdot 30 \times 10^{6} \mathrm{~L}-\mathrm{RNA}$, but an increased amount of the $0.56 \times 10^{6}$ component together with an additional component of molecular weight $0.77 \times 10^{6}$ (Fig. I $b$ ). Similarly, with RNA dissociated from purified ribosomes, the L-RNA present at $4{ }^{\circ} \mathrm{C}$ was almost completely absent at room temperature (Fig. I $c, d$ ).

Analysis at room temperature of RNA dissociated from the separated ribosomal subunits confirmed that the large subunit was the origin of the two smaller RNA components. As shown in Fig. 2, the large subunit contained two major components, in the molar ratio $1 \cdot 0: 1 \cdot 05$, of molecular weights $0.77 \times 10^{6}$ and $0.56 \times 10^{6}$ respectively, whereas the small subunit contained a single major peak of molecular weight $0.83 \times 10^{6}$. The presence of a $\mathrm{I}^{\circ} 07 \times 10^{6}$ component suggests some contamination of the cytoplasmic ribosomal subunits by bipolar body ribosomes (Spencer \& Cross, 1975).

The additive molecular weight of the two smaller components was always approximately that of the L-RNA molecule at $4{ }^{\circ} \mathrm{C}$, and it was therefore proposed that the former were degradation products of the latter. Non-specific ribonuclease activity in vitro was eliminated as the cause of the degradation because the products were always the same two specific components, and no degradation of $E$. coli rRNA was observed when it was co-extracted 


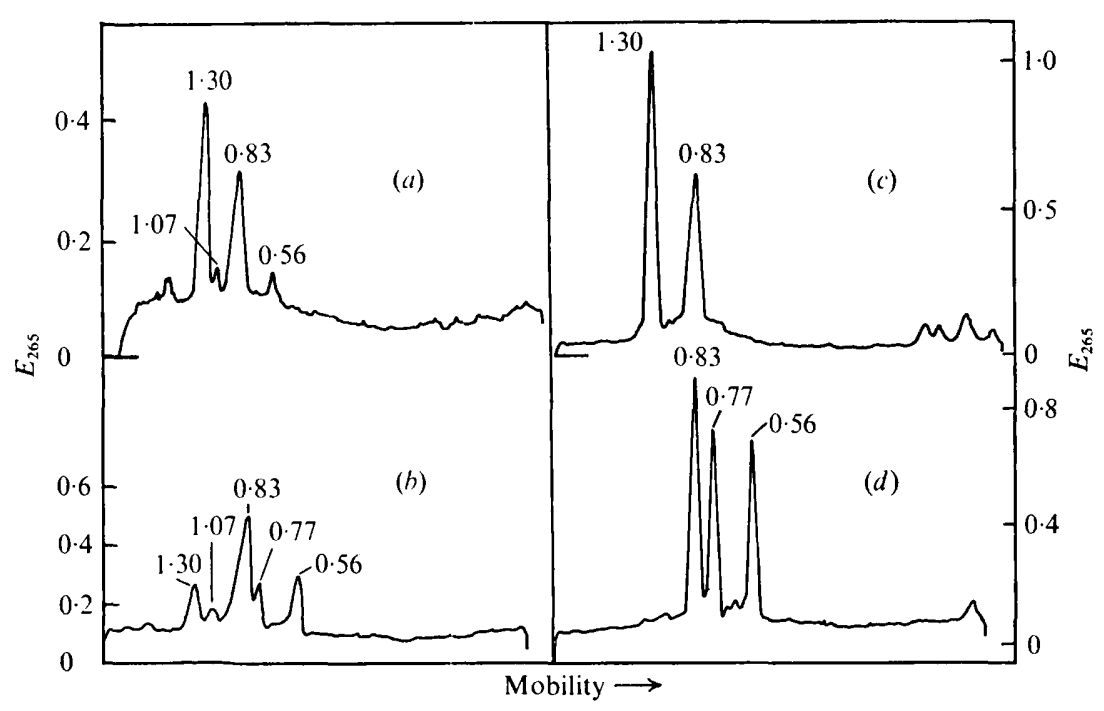

Fig. I. Crithidia oncopelti rRNA analysed at $4{ }^{\circ} \mathrm{C}$ and at room temperature. rRNA was dissolved in acetate buffer containing $5 \%(\mathrm{w} / \mathrm{v})$ sucrose. Ribosomes were diluted with acetate buffer containing $5 \%(\mathrm{w} / \mathrm{v})$ sucrose and $0.05 \%(\mathrm{w} / \mathrm{v})$ SDS. Electrophoresis was performed for $2 \mathrm{~h}(c), 2.5 \mathrm{~h}(a)$ or $3 \mathrm{~h}(b, d)$. Marker RNA was $E$. coli (molecular weights $1 \cdot 07 \times 10^{6}$ and $\left.0.56 \times 10^{6}\right)$. (a) rRNA extracted from cells and analysed at $4{ }^{\circ} \mathrm{C}$ (load: $6 \mu \mathrm{g}$ ); $(b)$ rRNA from the same extract as (a), analysed at room temperature (load: $18 \mu \mathrm{g}$ ); (c) RNA dissociated from purified cytoplasmic ribosomes and analysed at $4{ }^{\circ} \mathrm{C}$ (load: $20 \mu \mathrm{g}$ ribonucleoprotein); $(d)$ RNA dissociated from the same ribosome batch as $(c)$, analysed at room temperature (load: $20 \mu \mathrm{g}$ ribonucleoprotein).

and analysed at $4{ }^{\circ} \mathrm{C}$ or at room temperature with $C$. oncopelti $\mathrm{rRNA}$. Further degradation of extracted RNA from $C$. oncopelti was not demonstrable at room temperature even after storage for up to 3 months at $-20^{\circ} \mathrm{C}$. It was therefore proposed that extracted L-RNA contained a single 'hidden' break; at $4{ }^{\circ} \mathrm{C}$ the molecule appeared to be intact, but the conditions of electrophoresis at room temperature were marginal for preservation of the secondary structure of the molecule, resulting in some dissociation and consequent exposure of the break.

The extent to which L-RNA dissociation was temperature-dependent is shown in Fig. 3. Extracted rRNA was stable to brief heating up to $19{ }^{\circ} \mathrm{C}$; beyond this temperature dissociation of the L-RNA $\left(\mathrm{I} \cdot 30 \times 10^{6}\right)$ occurred, and by $5 \mathrm{I}^{\circ} \mathrm{C}$ the molecule was completely dissociated (via an intermediate $0.77 \times 10^{6}$ molecule) into two components of molecular weights $0.70 \times 10^{6}$ and $0.56 \times 10^{6}$. The dissociation products were present in approximately equimolar amounts to each other and to the $0.83 \times 10^{6}$ RNA (S-RNA), which remained unaffected by the treatments. From the data replotted in Fig. 4, it was estimated that $50 \%$ dissociation of the L-RNA occurred at $28{ }^{\circ} \mathrm{C}$, in agreement with other systems where the effect has been observed in solutions of ionic strength about 0.2 (Bostock et al., 197I; Leaver, 1973). Whether raising the salt concentration had any effect on the melting temperature of the L-RNA was not investigated.

In the absence of degradative enzymes, RNA molecules containing an intact phosphodiester backbone can withstand heating to $80^{\circ} \mathrm{C}$ for a few minutes (Stanley \& Bock, 1965), but any ribonuclease activity in the sample would be accelerated at this temperature (Atchison, Bourque \& Wildman, 1973). That complete dissociation of the L-RNA from C. oncopelti at $5 \mathrm{I}{ }^{\circ} \mathrm{C}$ is due to a latent break in the molecule, and is not a consequence of RNAase 


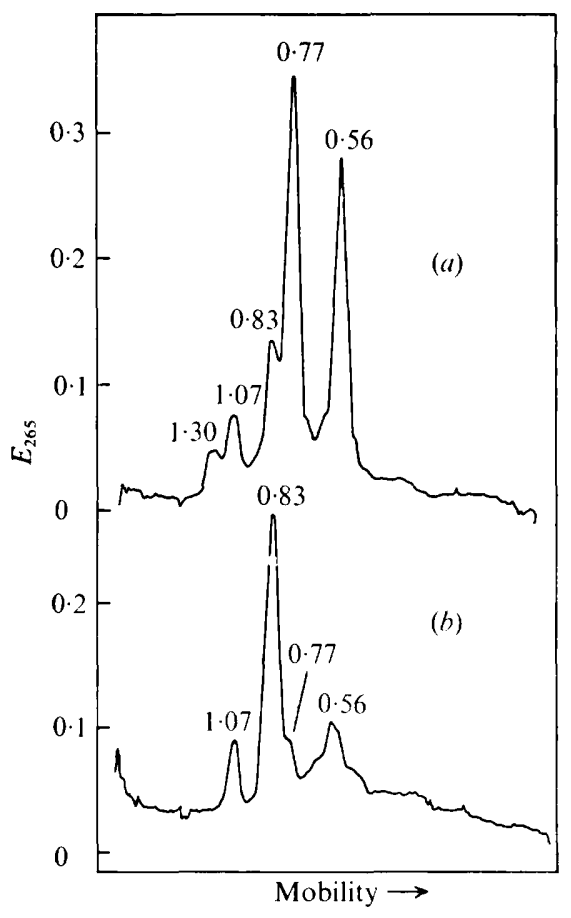

Fig. 2

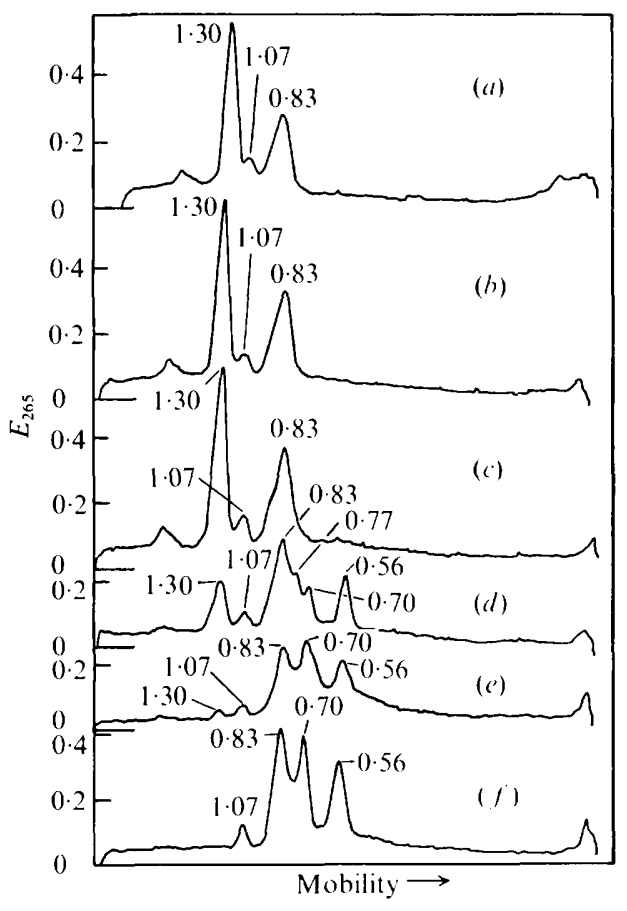

Fig. 3

Fig. 2. RNA content of separated ribosomal subunits. Subunits were prepared by sucrose gradient centrifugation. Up to $20 \mathrm{mg}$ ribonucleoprotein were layered on to $50 \mathrm{ml}$ linear gradients of 10 to $25 \%$ sucrose in $50 \mathrm{~mm}-\mathrm{KCl}$, I mM-magnesium acetate, $50 \mathrm{~mm}$-tris- $\mathrm{HCl}, \mathrm{pH} 7.6$, and centrifuged at $62300 \mathrm{~g}$ for $\mathrm{I} 0 \mathrm{~h}$ at $4^{\circ} \mathrm{C}$ in the SW 25.2 rotor of the Beckman L2-65B preparative ultracentrifuge. After centrifugation the gradients were displaced at $4{ }^{\circ} \mathrm{C}$ through a Uvicord I mm flow cell, and the extinction monitored at $254 \mathrm{~nm}$. Fractions containing 60 s and 40 s subunits (Cross, 1970) were pooled separately, diluted with $50 \mathrm{~mm}-\mathrm{KCl}, 50 \mathrm{~mm}$-tris- $\mathrm{HCl}, \mathrm{pH} 7 \cdot 6$, and the $\mathrm{Mg}^{2-}$ adjusted to $3 \mathrm{~mm}$. The subunits were collected by centrifugation at $165000 \mathrm{~g}$ for $3 \mathrm{~h}$ at $4{ }^{\circ} \mathrm{C}$, and immediately diluted with phosphate buffer $\div 0.2 \%(\mathrm{w} / \mathrm{v})$ SDS. Electrophoresis was for $3 \mathrm{~h}$ at room temperature. $(a)$ RNA dissociated from the large subunit ( $35 \mu \mathrm{g}$ ribonucleoprotein); (b) RNA dissociated from the small subunit ( $17 \mu \mathrm{g}$ ribonucleoprotein).

Fig. 3. The effect of brief incubation of rRNA at various temperatures before analysis. Samples $(0.2 \mathrm{ml})$ of an rRNA extract $(0.5 \mathrm{mg} / \mathrm{ml}$ in acetate buffer without SDS) were heated in a water bath at various temperatures for $5 \mathrm{~min}$ and then plunged on to ice. After the last sample had been cooled at $0^{\circ} \mathrm{C}$ for $30 \mathrm{mins}, 20 \mu \mathrm{l}$ portions of each sample were electrophoresed at $4{ }^{\circ} \mathrm{C}$ for $2.5 \mathrm{~h}$. (a) Control sample, kept on ice before analysis; $(b)$ to $(f)$, RNA heated for 5 min at I9, 25, 3I, 40 and $5 \mathrm{I}{ }^{\circ} \mathrm{C}$, respectively.

activity in vitro, was confirmed by analysis of the RNA in formamide gels. In completely denaturing conditions, without prior heat treatment, $C$. oncopelti rRNA consisted of three major components of average molecular weights $0.83 \times 10^{6}, 0.70 \times 10^{6}$ and $0.56 \times 10^{6}$ (Fig. 5). The molecular weights of $C$. oncopelti rRNA determined in aqueous and denaturing conditions are summarized in Table $\mathbf{I}$. 


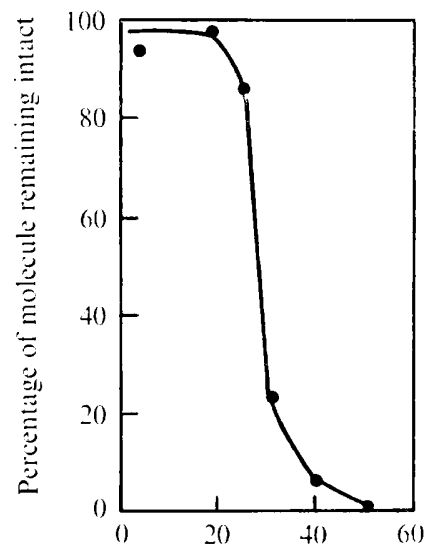

Pretreatment temperature $\left({ }^{\circ} \mathrm{C}\right)$

Fig. 4

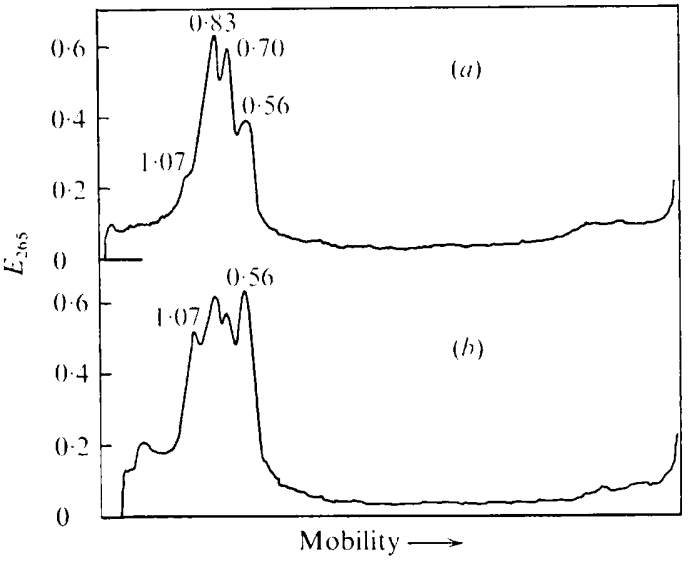

Fig. 5

Fig. 4. Effect of temperature on the stability of L-RNA from $C$. oncopelti. The percentage of intact L-RNA is expressed relative to S-RNA after the different temperature treatments shown in Fig. 3.

Fig. 5. Electrophoresis of $C$. oncopelti rRNA under fully denaturing conditions. rRNA was dissolved in $98 \%(\mathrm{v} / \mathrm{v})$ formamide containing $20 \mathrm{mM}-\mathrm{NaCl}$ and $5 \%(\mathrm{w} / \mathrm{v})$ sucrose. Electrophoresis was performed at $20^{\circ} \mathrm{C}$ for $4 \mathrm{~h}$. (a) Crithidia oncopelti rRNA $(30 \mu \mathrm{g}) ;($ b) C. oncopelti rRNA $(30 \mu \mathrm{g})$ + E. coli rRNA $(7 \mu \mathrm{g})$.

Table I. Average molecular weights of cytoplasmic $r$ RNA extracted from $C$. oncopelti and analysed under various conditions

\begin{tabular}{|c|c|c|}
\hline Conditions of electrophoresis & $\begin{array}{l}\text { No. of } \\
\text { experiments }\end{array}$ & $\begin{array}{c}10^{-6} \times \text { Molecular weights of major components } \\
\text { present }( \pm \text { S.D. })^{*}\end{array}$ \\
\hline Aqueous, $4^{\circ} \mathrm{C}$ & I4 & $I \cdot 30( \pm 0.03), 0.83( \pm 0.02)$ \\
\hline $\begin{array}{l}\text { Aqueous, room temperature } \\
\left(19-25^{\circ} \mathrm{C}\right)\end{array}$ & 15 & {$[\mathrm{I} \cdot 28( \pm 0.04)], 0.86( \pm 0.03), 0.77( \pm 0.02), 0.56 \dagger$} \\
\hline $98 \%(v / v)$ formamide & 3 & $0.83( \pm 0.03), 0.70( \pm 0.01), 0.56 \dagger$ \\
\hline
\end{tabular}

\section{DISCUSSION}

Evidence is presented which suggests RNA from the large ribosomal subunit of $C$. oncopelti (L-RNA, $\mathrm{r} \cdot 30 \times 1 \mathrm{I}^{6}$ ) contains a 'hidden' break at a unique position. At normal salt concentrations and low temperatures the extracted molecule is held together by its secondary structure. Procedures which disrupt non-covalent bonds (raised temperatures, formamide treatment) cause unfolding of the molecule, resulting in its conversion to fragments of molecular weights $0.70 \times 10^{6}$ and $0.56 \times 10^{6}$.

Dissociation was independent of whether the RNA had been extracted directly from cells or dissociated from purified ribosomes, suggesting the break is caused in vivo by a ribonuclease associated with the ribosomes. Intact rRNA is not essential for ribosome functioning in vitro (Szer, 1969, Hüvös, Gaál \& Vereczkey, 1972; Grove \& Johnson, 1973), and if this is also true for ribosomes functioning in vivo then lability of the molecule could reflect its random digestion within the ribosome. Non-specific association of ribonuclease with ribosomes has been demonstrated in many organisms (see Barnard, 1969, for review) and 
the specificity of degradation could reflect the accessibility of RNA within the ribosome to non-specific enzyme action (Dessev \& Grancharov, 1973). There is, however, some evidence from 3 -terminal sequence analyses that the latent scissions in insect rRNA reflect specific nuclease activity (Shine, Hunt \& Dalgarno, 1974). Furthermore, in organisms where precursor molecules to labile L-RNA have been studied by pulse-chase experiments, newly synthesized L-RNA was stable (Applebaum et al., 1966; Greenberg, 1969). Thus lability of the L-RNA of $C$. oncopelti may be a result of specific cleavage occurring during RNA maturation.

Whether the change in mobility of the larger dissociation product from $0.77 \times 10^{6}$ to $0.70 \times 10^{6}$ (see Fig. $3 d$ ) at intermediate temperatures reflects a conformational change within the molecule, or the further dissociation of a small fragment as has been found in other eukaryotes (Pene, Knight \& Darnell, 1968; Stevens \& Pachler, 1972) is uncertain, since the occurrence of low molecular weight RNAs after denaturation of L-RNA was not investigated.

Reijnders et al. (1973) briefly reported that $C$. luciliae L-RNA contains a hidden break at a unique position. Their estimates for the molecular weights of rRNA from this organism were $\mathrm{I} \cdot 38 \times 10^{6}$ and $0.83 \times 10^{6}\left(\right.$ at $4{ }^{\circ} \mathrm{C}$ ) and $0.83 \times 10^{6}, 0.74 \times 10^{6}$ and $0.56 \times 10^{6}$ (in 8 M-urea at $60{ }^{\circ} \mathrm{C}$ ), in agreement with those reported here for $C$. oncopelti. They found that in denaturing conditions the L-RNA from $C$. luciliae, isolated by sucrose gradient centrifugation from total cell sap RNA, consisted of the $0.83 \times 10^{6}$ and $0.56 \times 10^{6}$ components. However, the present work, in which the RNA species were obtained from separated ribosomal subunits in addition to whole cells, suggest that the $0.83 \times 10^{6}$ RNA component was incorrectly assigned to the large subunit by Reijnders et al. (I973).

In the course of this work, similar dissociation products were noted for the L-RNA from C. fasciculata and Trypanosoma brucei. Thus labile L-RNA may be a feature common to all trypanosomatid flagellates.

Loening (1968a) noted a constant molecular weight of about $0.7 \times 10^{6}$ for S-RNA from eukaryotes, and distinguished two classes of L-RNA: plants and protozoa contain L-RNA of constant molecular weight $1 \cdot 3 \times 10^{6}$ whereas L-RNA from higher animals has evolved in size from $\mathrm{I}_{4} 4 \times 10^{6}$ to $\mathrm{I} \cdot 75 \times 10^{6}$. However, two exceptions to this general classification were rRNAs from A. castellanii $\left(\mathrm{I}^{\circ} 53 \times 10^{6}\right.$ and $\left.0.89 \times 10^{6}\right)$ and Euglena gracilis $\left(\mathrm{I} \cdot 3 \times 10^{6}\right.$ and $\left.0.85 \times 10^{6}\right)$. L-RNA from both of these organisms is unstable, as in C.oncopelti, and the S-RNA in all three organisms is larger than usual. It is possible that L-RNA lability in these organisms reflects differences in rRNA maturation or ribosome structure from other protists.

\section{REFERENCES}

Applebaum, S. W., Ebstein, R. P. \& Wyatt, G. R. (1966). Dissociation of ribosomal ribonucleic acid from silkmoth pupae by heat and dimethyl sulphoxide: evidence for specific cleavage points. Journal of Molecular Biology 21, 29-4I.

Atchison, B. A., Bourque, D. P. \& Wildman, S. G. (1973). Preservation of 23s chloroplast RNA as a single chain of nucleotides. Biochimica et biophysica acta 331, 382-389.

Barnard, E. A. ( 1969). Ribonucleases. Annual Reviews of Biochemistry 38, 677-732.

Bishop, D. H. L., Claybrook, J. R. \& Spiegelman, S. (I967). Electrophoretic separation of viral nucleic acids on polyacrylamide gels. Journal of Molecular Biology 26, 373-387.

Borda, L., Green, M. H. \& Kamen, M. D. (1969). Sedimentation properties of ribonucleic acid from Rhodopseudomonas spheroides. Journal of General Microbiology 56, 345-35I.

Bostock, C. J., Prescott, D. M. \& Lauth, M. (197I). Lability of $26 \mathrm{~s}$ ribosomal RNA in Tetrahymena pyriformis. Experimental Cell Research 66, 260-262.

Cox, R. A. \& Littauer, U. Z. (I962). Ribonucleic acid from Escherichia coli. III. The influence of ionic strength and temperature on hydrodynamic and optical properties. Biochimica et biophysica acta 6r, $197-208$. 
Cross, G. A. M. (1970). Sedimentation properties of polyribosomes, ribosomes and ribosomal subunits from Crithidia oncopelti. Biochimica et biophysica acta 204, 470-477.

Dessev, G. N. \& Grancharov, K. (I973). Degradation of ribonucleic acid in rat liver ribosomes. Journal of Molecular Biology 76, 425-444.

Greenberg, J. R. (1969). Synthesis and properties of ribosomal RNA in Drosophila. Journal of Molecular Biology 46, 85-98.

Grove, B. K. \& Johnson, T. C. (1973). The effect of ribonuclease on ribosomal RNA and subsequent polypeptide synthesis. Biochemical and Biophysical Research Communications 55, 45-5I.

Herskovits, T. T. (1962). Nonaqueous solutions of DNA: factors determining the stability of the helical configuration in solution. Archives of Biochemistry and Biophysics 97, 474-484.

Hüvös, P., GAÁL, O. \& VERECZKEY, L. (1972). Effect of degradation of rat-liver ribosomal RNA on the structure of the ribosomal subunits. European Journal of Biochemistry 26, 518-527.

INGLE, J. (I968). Synthesis and stability of chloroplast ribosomal RNAs. Plant Physiology 43, I448-I 454.

ISHIKAWA, H. (1973). Primary and secondary nicks in the ribosomal ribonucleic acid of insects. Biochemical and Biophysical Research Communications 54, 30I-307.

KIRBY, K. S. (I965). Isolation and characterization of ribosomal ribonucleic acid. Biochemical Journal $\mathbf{9 6}$, 266-269.

LEAVER, C. J. (1973). Molecular integrity of chloroplast ribosomal ribonucleic acid. Biochemical Journal I35, 237-240.

LESSIE, T.S. (I965). The atypical ribosomal RNA complement of Rhodopseudomonas spheroides. Journal of General Microbiology 39, 3 I I-320.

LoENING, U. E. (1967). The fractionation of high-molecular-weight ribonucleic acid by polyacrylamide-gel electrophoresis. Biochemical Journal ro2, 25 I-257.

LoENING, U. E. (1968a). Molecular weights of ribosomal RNA in relation to evolution. Journal of Molecular Biology 38, 355-365.

LOENING, U. E. (1968b). The fractionation of high molecular weight RNA. In Chromatographic and Electrophoretic Techniques, vol. 2, 2nd edn, pp. 437-442. Edited by I. Smith. London: Heinemann Ltd.

NewTon, B. A. (1957). Nutritional requirements and biosynthetic capabilities of the parasitic flagellate Strigomonas oncopelti. Journal of General Microbiology 17, 708-71 7 .

PARISH, J. H. \& KIRBY, K. S. (I966). Reagents which reduce interactions between ribosomal RNA and rapidly-labelled RNA from rat liver. Biochimica et biophysica acta 129, 554-562.

Pene, J. J., KNight, E. \& Darnell, J. E. (1968). Characterisation of a new low molecular weight RNA in Hela cell ribosomes. Journal of Molecular Biology 33, 609-623.

Reijnders, L., Sloof, P., Sival, J. \& Borst, P. ( 1973). Gel electrophoresis of RNA under denaturing conditions. Biochimica et biophysica acta 324, 320-333.

Shine, J. \& Dalgarno, L. (I973). Occurrence of heat-dissociable ribosomal RNA in insects: the presence of three polynucleotide chains in 26s RNA from cultured Aedes aegypti cells. Journal of Molecular Biology 75, 57-72.

Shine, J., Hunt, J. A. \& Dalgarno, L. (I974). Studies on the $3^{\prime}$-terminal sequences of the large ribosomal ribonucleic acid of different eukaryotes and those associated with 'hidden' breaks in heat-dissociable insect 26 s ribonucleic acid. Biochemical Journal r41, 61 7-625.

SPENCER, R. \& Cross, G. A. M. (I975). Purification and properties of nucleic acids from an unusual cytoplasmic organelle in the flagellate protozcan Crithidia oncopelti. Biochimica et biophysica acta 390, I4I-154.

Stanley, W. M. \& Bock, R. M. (I965). Isolation and physical properties of the ribosomal ribonucleic acid of Escherichia coli. Biochemistry 4, I302-I $31 \mathrm{I}$.

Staynov, D. Z., Pinder, J. C. \& Gratzer, W. B. (I972). Molecular weight determination of nucleic acids by gel electrophoresis in non-aqueous solution. Nature New Biology 235, I08-I IO.

Stevens, A. R. \& Pachler, P. F. (I972). Discontinuity of 26 s rRNA in Acanthamoeba castellani. Journal of Molecular Biology 66, 225-237.

SzER, W. (1969). Enzymic degradation of ribosomal RNA in isolated purified ribosomes. Biochemical and Biophysical Research Communications 35, 653-658. 